\title{
Phæothamnion Confervicolum, Lagerheim, And Its First Recorded Appearance In Great Britain
}

\section{F. L. M'Keever F.R.M.S.}

To cite this article: F. L. M'Keever F.R.M.S. (1912) Phæothamnion Confervicolum, Lagerheim, And Its First Recorded Appearance In Great Britain, Transactions of the Botanical Society of Edinburgh, 24:1-4, 176-181, DOI: 10.1080/03746601209468958

To link to this article: http://dx.doi.org/10.1080/03746601209468958

曲 Published online: 29 Nov 2010.

Submit your article to this journal $₫$

Wlll Article views: 2

Q View related articles $₫$ 
longi inserta, 40-50, 14-16 mm. longa, omnia fertilia, libera, æqualia, filamentis filiformibus, antheris ovalibus, nec oblongis, dorso basi affixis. Ovarium longe stipitatum 4-6 costatum, stigmate sessili, glabrum, 7-8 mm. longum, 4-6 loculare. Fructus immaturus ad $4-5 \mathrm{~cm}$. elongatus, 2-3 mm. latus, carnosulus, seminibus haud multis, multum compressis, reniformibus, $3 \mathrm{~mm}$. longis, gynophoro ad 2-3 cm. aucto.

Burma :-Ad vicum Loi-mwe dictum apud pagos shanenses australes. circ. 1500 ped. alt. 714, 1325, R. W. MacGregor. Typi in herbario Calcuttensi conservati.

\section{DESCRIPTION OF PLATE.}

Figure A. Branch with inflorescence. $\times 1$.

,$\quad$ B. Flower dissected. $\times 2$.

" C. Petal. $\times 4$.

" D. Section or ovary; seed. $\times 2$.

Phaothamion Confervicolum, Lagerheim, and its First Recorded Appearance in Great Britain.* By F. L. M'KeEver, F.R.M.S.

The large class of Algæ, the Phæophyceæ or Fucoideæ (in older books usually called Melanosporeæ), are almost entirely inhabitants of the sea, and only a few families of the order Syngeneticæ are found in fresh water. G. S. West (1) enumerates seven families of this order, and of these only four are represented in Great Britain. I was fortunate enough to find the only member of the fifth family, the Phæothamniaceæ, among other Algæ collected from the Elf Loch on the Braid Hills near Edinburgh, and a few remarks on this plant might be of some interest.

Phæothamnion confervicolum was first described by the Swedish botanist G. Lagerheim, who published his description, together with a very complete life-history, in 1884 (2). He had found this Alga in several localities in Sweden as an epiphyte on various filamentous Chlorophyceæ, and as

* "Annals of Scottish Natural History," No. 77, January 1911. 


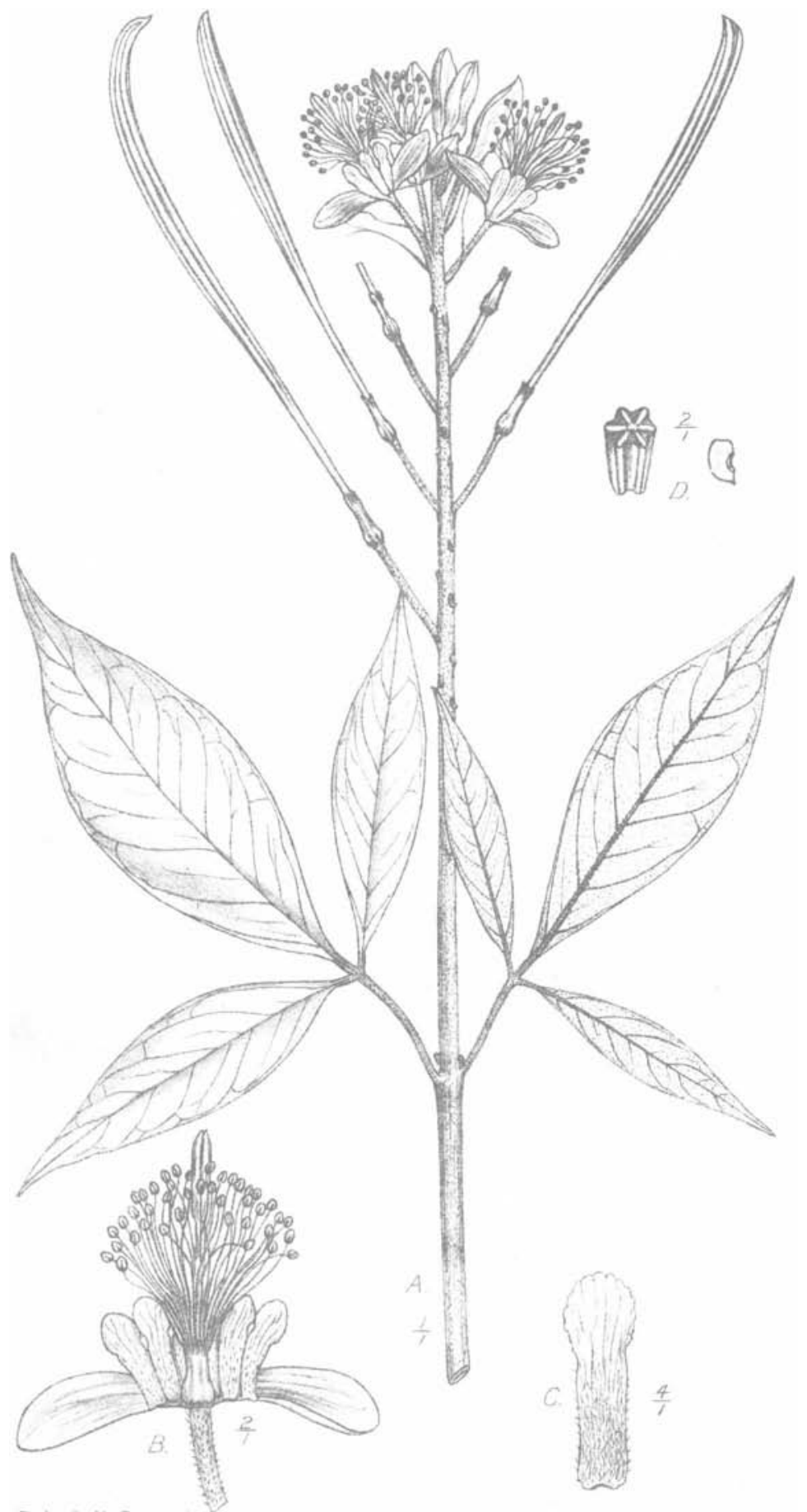

Del. A.N. Banerjee

BORTHWICKIA TRIFOLIATA. W. W Smith 
the brown chromatophore distinguishes it at once from all other known freshwater Algæ, he established the new genus Phæothamnion. He suggests, however, to create a subfamily, Phæothamnieæ of the Chætophoraceæ (Harv.) Wittr., the latter being a family of the Chlorophyceæ or Green Algæ.

The description of this Alga given by Lagerheim (2) is as follows :-

"Thallus confervoideus (non mucosus) monopodialiter ramosus, ramis superioribus suberectis, ramis inferioribus patentibus, algis majoribus adnatus. Cellulæ vegetativæ cylindrica vel subclavatæ vel ovoideæ; cellulæ terminales obtusæ vel acutatæ, nunquam piliferæ; cellula basalis subhemisphærica, basi in disculum dilatata; nembrana cellularum tenuis et hyalina, septis incrassatis; chromatophoræ laminæformes, parietales, fusco-virides vel olivaceæ (colore orto e chlorophyllo cum phycoxanthino mixto). Zoosporangia intercalaria e cellulis vegetativis orta, eadem forma ac cellulæ vegetativæ. Zoosporæ binæ, bipartitione contenti zoosporangii ortæ, olivaceo-virides, puncto rubro nullo, ciliis vibratoriis binis in fine anteriore zoosporæ positis præditæ, per ostiolum poriforme zoosporangii examinantes, sine conjugatione germinantes. Cellulæ vegetativæ (membrana in mucum gelatinosum mutata) bipartitione succedanea in statum palmellaceum transeuntes."

The dimensions given by Lagerheim are as follows :--

Long. cell. veg. $6-10 \mu$; lat. cell. veg. $4-8 \mu$.

$$
\begin{aligned}
& \text { " " apic. } 6-12 \mu ; \quad, \quad \text {, apic. } 4-6 \mu \text {. } \\
& \text { " " bas. } 5-6 \mu \text {; " , bas. } 9 \mu \text {. } \\
& \text { "zoosporang. 6-10 ; ; , zoosporang. } 5-8 \mu \text {. }
\end{aligned}
$$

Diam. orif. zoosporang. $3 \mu$; diam. zoosporang. $4-5 \mu$.

$$
\text { cell palmell. } \quad 4 \mu \text {. }
$$

Total height of plant up to $100 \mu$.

Twenty-one figures on one plate were also published in Lagerheim's paper (2).

The plant was distributed in Wittrock and Nordstedt's "Algæ aquæ dulcis exsiccatæ," fasc. 13, No. 608.

Two years later this Algæ was described by A. Hansgiry in the first volume of his "Algaflora of Bohemia" (3), and he placed the family Phæothamnieæ under the order Syngene- 
ticæ of the Phæophyceæ or Brown Algæ. Hansgirg's description and sketch enabled me to identify the Alga I had found as an epiphyte on aquatic phanerogams in the Elf Loch, especially as it was easily distinguishable from all the other freshwater Algæ by its brown chromatophore. Professor G. S. West of Birmingham, to whom I sent some living specimens of Phæothamnion, confirmed my identification. He had already pointed out in 1904 (1) that this AIga would be found one of these days in Great Britain, and, as nearly all freshwater algæ are cosmopolitan, it is not surprising that it should be discovered in this country also. As far as I can ascertain, it was recorded after 1886, the date of Hansgirg's publication, from the following localities :-

1888. G. Lagerheim (5): Sphagnum near Halensee, and on Cladophora from Tempelhof, both places near Berlin; on Vaucheria in the Botanical Gardens of Wuirzburg, Bavaria, and also from Freiburg in the grand-duchy of Baden.

1892. Borzì (6) in Sicily, near Messina.

1892. A. Hansgirg (4), in the second volume of his "Algaflora of Bohemia."

I could not find any other record of Phæothamnion except one in 1905, published again by A. Hansirg in his "Algaflora of Lower Austria" (7). The only other investigation regarding the life-history of Phæothamnion confervicolum, besides that given by G. Lagerheim in 1884 (2), was published by Borzi of Italy in 1892 (6). There are several important points in which Borzì differs from Lagerheim, such as the position of the zoospores and the presence of a red pigment spot. Lagerheim reports bi-ciliated asexual zoospores only, without a pigment spot, while Borzi has observed gametes and a red eye spot as is usually found in the zoospores of the higher forms of Algæ. Lagerheim distinctly states that the two cilia of equal length are inserted in the anterior part of the zoospores, and Borzi describes the cilia to be directed laterally as observed among the Phæophyceæ. It would therefore be desirable to reinvestigate the motile stages of Phæothamnion, as the position of the cilia is of considerable importance for the systematist. 
I first observed this Alga in its younger stages growing on the rootlets of Lemna minor and the leaves of some aquatic phanerogams, but it grew later on in great profusion together with Coleochæte scutata, Bréb., on the sides of the glass vessel in which I preserved various species of Algæ collected from the Elf Loch. Although kept in cultivation for over two months during August and September 1910, I could only observe the vegetative stage of this plant. After an absence of several weeks I found Phæothamnion had entirely disappeared from the culture, and to my great regret I was unable to contribute anything to our knowledge of the life-history of this algæ.

A Palmella-stage such as is reported both by Lagerheim and Borzi I was unable to obtain even by varying the conditions under which the plant grew in "hanging-drop" cultures. Empty cells showing the characteristic circular opening by which the zoospores had escaped I found several times, and also in one instance a few zoospores, but owing to lack of time I was unable to fix and stain these in order to investigate the number and position of the cilia.

Regarding the remarkable colour of the chromatophore, I can confirm Lagerheim's and other investigators' statements as to the action of a weak alcoholic solution, which dissolves the brown colouring matter and leaves the green chlorophyll, and exactly the same effect can be obtained with the brown chromatophores of the Diatomaceæ.

The systematic position of Phrothamnion and the other lower Phæophyceæ was thoroughly investigated by $\mathrm{A}$. Scherffel in 1900 (8) and 1901 (9), and also by Oltmanns in 1904 (10). De Toni in his "Sylloge Algarum," vol. iii., published in 1895 (11), places Phæothamnion, following Hansgirg, under the Phæophyceæ or Fucoideæ. N. Wille, in Engler and Prantl's "Natuirliche Pflanzenfamilien" (12), however, regards this Alga, as was suggested by its discoverer Lagerheim, as a genus of the family Chætophoraceæ, and therefore one of the Chlorophyceæ or Green Algæ.

In Oltmann's great work on the Algæ (10), Phæothamnion and all the Unicellular Brown Algæ are considered apart from the class Phæophyceæ, and as being nearer related to the Flagellatæ than to the true Algæ. Phæothamnion is regarded by him as one of the Chrysomonadineæ, and 
described in an "Anhang zu den Chrysomonadinen" (see vol. i. pp. 12 and 15, vol. ii. pp. 18-19).

G. S. West in his "Treatise on the British Freshwater Algæ," published in 1904, as previously stated, mentions the following seven families as the most important of the freshwater Phæophyceæ:-

Fam. Hydruraceæ, with Hydrurus, Ag.

" Cryptomonadinaces, with Cryptomonas, Ehrenb.

"Chrysomonadinacex, with Syncrypta, Ehrenb.; Synura, Ehrenb.; Uroglena, Ehrenb.

, Dinobryace e, with Dinobryon, Ehrenb.

" Pheocarsacee, with Pherengst is, Lagerh.; Pherocoecus, Borzi ; Plueosphcerce, West and G. S. West; Stichoglea, Chodat; Pheschirochlamys, Lemm.: Plueodactylon, Bohlin.

„ Choristocarpacede, with Pleurocladio, A. Br.

" Pheothamniaced, with Phoothamnion, Lagerh.

Up to 1910 only four of the above families were known to be represented in Britain.

In Thomé's "Kryptogamen Flora von Deutschland" (13), Migula has apparently followed Oltmanns by regarding all the lower Phæophyceæ as Flagellatæ, or rather as intermediate stages between them and the Algæ, as Phæothamnion, as well as Hydrurus, Phæocystis, and other Syngeticæ, are mentioned neither in vol. i., treating of the Myхорhyceæ, Chlorophyceæ, and Bacillaricæ, nor in vol. ii., devoted to the Phrophyceæ and Rhodophycer. A copy of figs. 7 and 10 of Lagerheim's plate, published in 1884 (2), appears, however, on plate 38 of vol. i. in Migula, but without any description in the text.

A bibliography of Phrothamnion, as far as I have been able to ascertain, is given below.

\section{BIBLIOGRAPHY.}

(1) G. S. West-A Treatise on the British Freshwater Algie, Cambridge, 1904, p. 45, and following.

(2) G. Lagerheim.-Ueber Phæothamnion, eine neue Gattung der Süss-wasseralgen. Bihang till K. Svenska Vet. Akad. Handlangar, ix. No. 19, Stockholm, 1884.

(3) A. Hansgirg.-Prodromus der Algenflora von Böhmen. Vol. i, Prague, 1886, p. 31. 
(4) A. Hansgirg.-Vol. ii., Prague, 1892, p. 207.

(5) G. Lagerhaim.- Sopra alcune Alghe d' acqua dolce nuove o rimarchevoli. Notarisia iii., fasc. 12, p. 592.

(6) A. Borzi.-Intorno allo sirluppo sessuale di alcune Feoficee inferiori. Atti del congresso botanico internazionale di Genova, 1892, pp. 454-462. Tav, xvii.

(7) A. Hansgir . - Grundzigge der Algenflora von Nieder-Oesterreich, Beitr. z. bot. Centralblatt, 1905, xviii., Abt. ii. Heft 3, p. 433.

(8) A. Scherfwel.--Phæocystis globosa nov. spec. nebst einigen Betrachtungen iiber die Phylogenie niederer insbesondere brauner Organisnen. Wissenschaftl. Meeresuntersuchungen, Abt. Helgoland, N.F. iv., 1900. $1^{\text {tes }}$ Heft.

(9) A. Scherffel.-Kleiner Beitrag zur Phylogenie einiger Gruppen niederer Organismen. Botan. Zeitung, 1901,59, pp. 143-158.

(10) F. Oltmanns.-Morphologie und Biologie der Algen, vol. i., 1904 ; vol. ii., 1905.

(11) De Tont.-Sylloge Algarum, vol. iii. (Fucoidex). Patavii, 1895, p. 120.

(12) N. Wille. - Engler and Prantl's Natïrliche Pflanzenfamilien, I. Teil, ii. Abt, p. 96. Leipzig, 1897.

(13) THomés Kryptogamen Flora von Deutschland, etc., bearbeite von W. Migula. Band ii., Algen. I. Teil. Gera, 1907.

Further Records of Flowering-Plants (Phanerogams) and Ferns from the Isle of May. By William Evans, F.R.S.E.

The following botanists have recorded their observations on the Flora of the Isle of May, at the mouth of the Firth of Forth :-

John Sadler ("Trans. Bot. Soc. Edin.," vol. xi. pp. 390$392,1873)$.

John Rattray (ibid., xvi. pp. 115-121, 1884).

William Evans (ibid., xxiii. pp. 348-351, 1908; and xxiv. pp. 91-93, 1910).

George West ("Proc. Roy. Soc. Edin.," xxx. pp. 173$177,1910)$.

With the exception of my own-which are concerned entirely with the Mosses and Hepatics-these papers deal more or less with the Phanerogams and Ferns. ${ }^{1}$ Sadler, who visited the island along with Professor J. H. Balfour

1 A few Fungi from the May have been recorded by Mr. A. B. Steele and myself "Ann. Scot. Nat. Hist." 1908, p. 58, and 1910, p. 58). To these there falls to be added Crucibulum vulgare, Tul., which I found in Sept. 1910 growing on a piece of old wood in the south garden. 